\title{
CGNL1 wt Allele
}

National Cancer Institute

\section{Source}

National Cancer Institute. CGNL1 wt Allele. NCI Thesaurus. Code C98065.

Human CGNL1 wild-type allele is located in the vicinity of 15q21.3 and is approximately $174 \mathrm{~kb}$ in length. This allele, which encodes cingulin-like protein 1, is involved in the formation of tight junctions. A chromosomal inversion that positions the CGNL1 gene promoter into a position close to the CYP19A1 gene coding region is associated with aromatase excess syndrome. 